\title{
Environmental Governance and a Poor Local Community : The Development of a Flood Control and Ecosystem Restoration Project in Hamilton City, California
}

\author{
Yoshitaka Miyake*
}

\begin{abstract}
This study analyzed environmental governance in advancing a project to restore part of the ecosystem along the Sacramento River near Hamilton City, California, and the response from residents of that poor local community demanding that the project include construction of a flood-protection levee. The theory and practice of environmental governance was analyzed in terms of scale politics. In Hamilton City, the integration of ecosystem restoration into a levee construction project has been actively pursued by a number of entities, and now includes far more than just the traditional interests from the local to federal scales. The project involves many organizations that take an interest in ecosystem restoration : nongovernmental organizations-including international ones-numerous governmental agencies traditionally engaged in river management-from federal down the power relation all the way to local—and local residents. Taking a broader view, non-governmental organizations and governments all along the Sacramento River created environmental governance to boost and participate in the restoration project. This created a rather horizontal relation among the related actors. The residents of Hamilton City accepted and participated in the ecosystem restoration project because they recognized its merit. Furthermore, the governments funding the project could not justify stand-alone levee construction. The Hamilton City residents continue their appeal to governmental and non-governmental agencies for funding to construct a levee. In this regard, resident efforts remain meaningful.
\end{abstract}

Key words Environmental governance, scale politics, levee construction, ecosystem restoration, the U.S.

\section{Introduction}

Environmental governance broadly concerns the type of decision-making and the type of participants to deal with environmental issues (Reed and Bruyneel, 2010). Normatively, this represents the shift of decision-making in environmental issues from vertical to horizontal ones (Harrington et al., 2008). In terms of environmental governance, environmental geographers are especially interested in the changing scale relations of participants and the corresponding power relations (Reed and Bruyneel, 2010).

This study explored the problem of environmental governance and geography through the integration of ecosystem restoration in flood control in Hamilton City, California. From the mid 1990s, governments

* Ph.D. Candidate, Department of Geography, the University of Hawai’i at Mānoa 
and environmentalists promoted ecosystem restoration on the Sacramento and San Joaquin River Basin while rural residents, especially farmers, resisted the progress (Singh, 2004). Hamilton City, a poor community, became a successful site to carry out ecosystem restoration with flood control as it seemed to involve both public agencies and local people (Bundy, 2003, p. 1). Thus, the project in Hamilton City could show the change of environmental governance: the way both agencies and local people got engaged in adding ecosystem restoration to flood control.

Therefore, this study explores the change of environmental governance and the power of a corresponding poor local community by the combined flood control and ecosystem restoration project in Hamilton City along the Sacramento River, California from the 1970s to 2004. The Hamilton City project evolved from the attempt of local residents to construct a levee to a project encompassing flood control and ecosystem restoration including the interests of state and federal agencies and environmental NPOs. This project led to the 2004 Hamilton City Study (Hamilton City Flood Damage Reduction and Ecosystem Restoration, California: Final Feasibility Report and Environmental Impact Statement/ Environmental Impact Report) (USACE and Reclamation Board, 2004). This study resulted in the current plan to integrate ecosystem restoration with levee construction. As explained in Chapter VII, this study involves the interests of major agencies and Hamilton City residents to conduct the integration of ecosystem restoration with levee construction.

\section{The Recent Discussion about Geography of Environmental Governance}

Reed and Bruyneel (2010) review environmental governance and power dynamics through scales, "the politics of scale" (p. 6). "The politics of scale" focuses the negotiation over the roles and power of actors among scales. According to Reed and Bruyneel (2010), environmental governance concerns styles of decision-making and their effects. Based on Harrington et al. (2008), environmental governance means the change of decision-making from the one involving formal, traditional, and centralizing institutions such as governments and traditional norms to the one with horizontal decision-making involving various institutions. Furthermore, following Bakker (2007) and Olsson (2007), Reed and Bruyneel say that environmental governance concerns rules, strategies, information, and the legitimacy of decision-makers beside types of participating actors. The impacts of decision-making are expressed as power relations, the legitimacy of information, the authority of decision-makers, the inclusiveness of public opinions, and material consequences (Reed and Bruyneel, 2010).

This broad interest in decision-making of environmental governance is shared with environmental geographers (Reed and Bruyneel, 2010). Reed and Bruyneel (2010) explain that environmental geography does not currently limit its interest to conventional actors any more. In short, environmental geographers became broadly curious about "who gets what ?" and "who decides?" in environmental governance (Reed and Bruyneel, p. 1). They investigate actors' purposes, possible actions, and their effects such as the impact of actions on a certain power relation.

Especially, geographers focus on "the politics of scale" as the base to consider questions of environmental governance as mentioned above (Bulekeley, 2005, p. 876 ; Reed and Bruyneel, 2010, p.6). According to Bulkeley, scholars of the network 
paradigm have criticized the focus on scale because the concept of scale possesses vertical and bounded implications. Bulkeley (2005) tries to reconcile this debate. Bulkeley argues that scale assumes the certain extent of flexibility of spatiality in the same way as network paradigm. Scale relations are neither continuously fixed nor conventional. As they are socially constructed, they can be contested (Brenner, 2001 ; Bulkeley, 2005, p. 883 ; Marston, 2000 ; McCann, 2003). In this sense, the state is reconsidered and reconfigured in relation to actors at other scales and newly participating actors. Paterson et al. (2003) argues that this shifts of state and "global environmental governance cannot be understood separately" (p. 7 ; cited in Bulkeley, 2005). Bulkeley claims that most studies on these broader shifts ignore the implication for environmental governance (p. 883). She suggests that the politics of scale could imply the goals and power of participating institutions (p. 890). Therefore, compared with conventional state-centered scale arrangement, environmental governance happens with changing scalar arrangements of institutions and has its own material consequence.

Thus, to understand environmental governance, geographers are interested in the goals and roles of participating organizations, their attainment and material consequences and their control over the project. They are especially interested in the role of scale among participants and its impact on participants' power and gain. In order to understand the change of environmental governance over the Hamilton City project, this study describes the roles and intentions of participating agencies and organizations in the chapters below.

\section{Methodology}

This case study used qualitative methodology. While the method of this study could not characterize a community based on detailed quantitative data, this could show the historical change of participants' attitudes and power. From April 2004 to March 2005, the meetings and events of community organizations were observed. The questionnaire survey was conducted in February 2005. Without enough responses, the results were used to make questions for interviews. Eight people were interviewed in the town in March 2005. Additionally, two state officials were interviewed in June 2005. They were asked the questions about the long-term processes of the Hamilton City project. Newspaper articles, flyers, minutes from public meetings, and technical reports were also collected.

\section{Hamilton City and its Flood Issue}

Hamilton City is an unincorporated town of Glenn County, California, ten miles $(16 \mathrm{~km})$ west of Chico. The town started as a company town of Holly Sugar in 1905 (Kackert, 1995) (Table 1). Hamilton City includes 1,903 people and 513 households and is surrounded by the agricultural land (USACE and Reclamation Board, 2004) (Fig. 1). The major social issues of the town include the poverty of Spanish-speaking workers. Their average per capita income was $\$ 9,015$, only $60 \%$ of the state average (USACE and Reclamation Board, 2004). In the 2000 U.S. Census, 1,533 of the 1,903 residents, $81 \%$, identify themselves as Hispanic or Latino in the town. ${ }^{1}$

More severely, Hamilton City has been concerned about flooding for more than thirty years. Hamilton City is on the Sacramento Valley's floor and has an 
Table 1 The Major Events of the Hamilton City Levee Project

\begin{tabular}{|c|c|c|}
\hline Year & Event & Major Actors \\
\hline 1905 & Holly Sugar constructed Hamilton City. & Holly Sugar \\
\hline $1907-1908$ & Holly Sugar constructed the "J" Levee. & Holly Sugar \\
\hline 1945 & Shasta Dam was constructed. & Federal Bureau of Reclamation \\
\hline The $1970 \mathrm{~s}$ & The Events of Local Struggle. & \\
\hline The 1970 s & Floods resumed to threaten Hamilton City. & \\
\hline 1975 & The study on the levee reconstruction was conducted. & USACE \\
\hline 1986 & The study on the levee reconstruction was conducted. & USACE \\
\hline 1996 & Holly Sugar closed. & Holly Sugar \\
\hline 1998 & $\begin{array}{l}\text { HCCSD started fundraising and handed this over to the } \\
\text { HCCIA. }\end{array}$ & HCCSD, HCCIA \\
\hline 1998 & The levee festivals started. & HCCIA, various town organizations \\
\hline The mid 1990s & Becoming Included in Wider Projects. & \\
\hline 1997 & The Comprehensive Study began. & USACE, Reclamation Board \\
\hline 1998 & $\begin{array}{l}\text { TNC began the purchase of Hamilton City farmland on the } \\
\text { actual floodplain. }\end{array}$ & TNC, DFG, CWCB, FWS \\
\hline 1999 & $\begin{array}{l}\text { The Comprehensive Study recognized the Hamilton City } \\
\text { project. }\end{array}$ & USACE, Reclamation Board \\
\hline 2001 & $\begin{array}{l}\text { The Comprehensive Study decided to study the Hamilton } \\
\text { City project. }\end{array}$ & USACE, Reclamation Board, HCCSD \\
\hline 2001-2002 & $\begin{array}{l}\text { TNC conducted studies to plan ecosystem restoration } \\
\text { with a new levee. }\end{array}$ & TNC, HCCSD \\
\hline$\underline{2002}$ & Drafting the 2004 Hamilton City Study. & \\
\hline 2002 & The Comprehensive Study was abandoned. & $\begin{array}{l}\text { USACE, Reclamation Board, state } \\
\text { and federal politicians }\end{array}$ \\
\hline 2002 & $\begin{array}{l}\text { CALFED decided to pay the local share of the } 2004 \text { Ham- } \\
\text { ilton City study. }\end{array}$ & $\begin{array}{l}\text { CALFED, USACE, Reclamation } \\
\text { Board }\end{array}$ \\
\hline 2002 & Meetings for the 2004 Hamilton City Study began. & $\begin{array}{l}\text { USACE, Reclamation Board, various } \\
\text { stakeholders }\end{array}$ \\
\hline 2004 & The 2004 Hamilton City Study is finalized and accepted. & \\
\hline
\end{tabular}

Produced by the author

approximate elevation of 145 feet (44 m) (Fig. 1). In early spring, the town historically faces flooding of the Sacramento River east of Hamilton City (USACE and Reclamation Board, 2004). To tackle this problem, Holly Sugar and local farmers constructed the levee from the north to the southeast of the town (Sacramento Valley Mirror [Artois, CA], 4 January 2003). This levee is commonly called the "J" Levee with no official name. After the Shasta Dam was constructed in 1945, the town experienced no significant flooding for thirty years. However, according to a town's resident, the HCCIA member and a state official, the "J"
Levee broke to cause floods and evacuations of town residents after the construction of the levee on the other side, the Butte County side, of the Sacramento River in the 1970s (interview 23/March/2005; 24/ March/2005 ; 3/June/2005). Currently, the river has eroded the "J" Levee so much that it has only a $66 \%$ probability to pass a ten-year event (USACE and Reclamation Board, 2004).

From the 1970 s to this day, the historical descriptions of human efforts for the Hamilton City project can be divided into the two periods as major events are shown on Table 1 . The first period explains the 


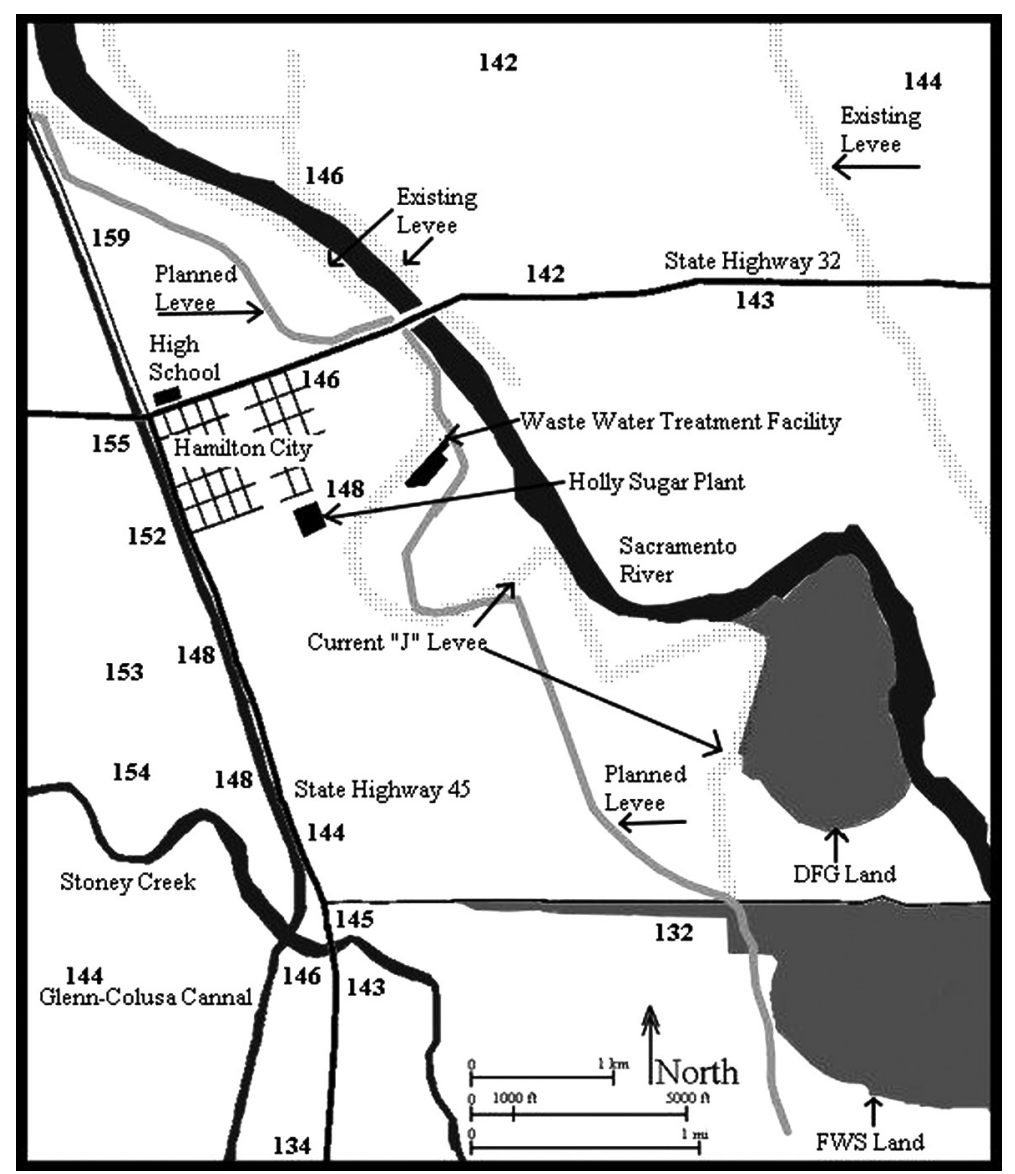

Fig. 1 Map of the Hamilton City Levee Project. Reproduced from USACE and Reclamation Board (2004, figure on summary : 1). The bold numbers indicate the elevation on each spot. These are transferred from USGS topographic maps.

events to 2002. These events are further divided into the two stories : the story about local struggles on the Hamilton City project and the story which frames the Hamilton City project within wider projects of outside organizations to combine ecosystem restoration with flood control. The second period spans from 2002 to 2004 to contain the story to show the development of the 2004 Hamilton City Study (USACE and Reclamation Board, 2004). Before the project's historical account, the basic nature of organizations involved and their roles in the project are explained.
V. Agencies and Organizations for the Hamilton City Project

The Hamilton City project involves various actors from local to federal scales (Table 2). This section is going to describe the basic nature of involved organizations. Without a town government, Hamilton City has Hamilton City Community Services District (HCCSD), the elementary and high schools as publicly recognized organizations. The HCCSD manages the town's sewer system. Civic organizations in the town include churches, Hamilton City Volunteer Fire 
Table 2 The Major Players of the Hamilton City Levee Project and their Abbreviation

\begin{tabular}{ll}
\hline \multicolumn{1}{c}{ Player's Scale or Nature } & \multicolumn{1}{c}{ Player Name (Its Abbreviation) } \\
\hline Hamilton City & $\begin{array}{l}\text { Hamilton City Community Services District (HCCSD), Hamilton City } \\
\text { Citizens in Action (HCCIA), Volunteer Fire Department, Service Clubs }\end{array}$ \\
\hline Glenn County & The County of Glenn, Glenn County Supervisors \\
\hline State Agencies & $\begin{array}{l}\text { The Reclamation Board, California Department of Fish and Game (DFG), } \\
\text { California Department of Water Resources (DWR), California Wildlife } \\
\text { Conservation Board (CAWCB), California Department of Transportation } \\
\text { (CalTrans), California Bay-Delta Authority }\end{array}$ \\
\hline Federal Agencies & $\begin{array}{l}\text { U.S. Army Corps of Engineers (USACE), U.S. Fish and Wildlife Service } \\
\text { (FWS) }\end{array}$ \\
\hline State and Federal Collaboration & CALFED Bay-Delta Program (CALFED) \\
\hline Professional and NGOs & $\begin{array}{l}\text { Sacramento River Conservation Area Forum (SRCAF), The Nature Con- } \\
\text { servancy (TNC), Attorney Bill Paris }\end{array}$ \\
\hline State and Federal Politicians & $\begin{array}{l}\text { Former State Assemblyman Dick Dickerson, Former State Senator Mau- } \\
\text { rice Johannessen, Congressman Wally Herger, Senator Barbara Boxer }\end{array}$ \\
\hline
\end{tabular}

Produced by the author

Department, school-related support group, the Women's Club, and Lions Club.

A member of Hamilton City Citizens In Action (HCCIA) explained its establishment as a voluntary organization in the mid 1990s (interview, 23/March/ 2005). Town's people established the HCCIA to represent their opinion like a town's council. To plan the organization, the high school principal initiated discussions with people in the town. About ten people in the town including the principal and a few HCCSD staffs gathered to form the group that is now called the HCCIA.

The HCCIA is not an elected group but includes a representative of each community entity in the town. The representatives attend the HCCIA meetings to discuss current issues of the town and their own organizations. The HCCIA also invites concerned people. Later, some of them have become the regular participants of the HCCIA. In the meetings, a few bilingual people are available to translate between English and Spanish. The HCCIA has dealt with town's issues such as unleashed dogs, deleting gang graffiti, and the cleanup of State Highway 32. To deal with these, it has cooperated with the County of Glenn. The other player in Hamilton City is Attorney Bill Paris. He specializes in the formation and maintenance of a levee district (A HCCIA member, interview, 23/March/ 2005). He is hired both by the HCCSD and HCCIA.

Various state agencies participated in the Hamilton City project. California Department of Water Resources (DWR) is broadly engaged in water resource issues. $^{2} \quad$ The Reclamation Board of the State of California (currently named Central Valley Flood Protection Board) is primarily engaged in flood control on the Sacramento and San Joaquin Rivers. ${ }^{3}$ For this purpose, the board cooperates with federal and state agencies such as the U.S. Army Corps of Engineers (USACE). Also, the board promotes public access to restoration sites. The California Department of Fish and Game (DFG) and the California Wildlife Conservation Board (CWCB) are interested in the conservation of wildlife, fish, and plants. The DFG manages eco- 
system for conservation and human use. ${ }^{4}$ The CWCB authorizes the budget to establish sanctuaries. ${ }^{5}$ Furthermore, California Department of Transportation (CalTrans) is involved. It normally improves and maintains the state's transportation system. ${ }^{6}$

As a federal agency, USACE conducts public work projects for military and civilian purposes. ${ }^{7}$ In addition, the USACE conducts ecosystem restoration and preservation. The U.S. Fish and Wildlife Service (FWS) conserves fish and wildlife. ${ }^{8}$ For this objective, the FWS acquires land to add its wildlife refuges. ${ }^{9}$

In addition, there is an agency based on the collaboration among state and federal agencies. The California Bay-Delta Program (CALFED) is a collaborative platform for 25 agencies both at state and federal levels to enhance state's water supply and ecosystem of the Sacramento and San Joaquin River basins. ${ }^{10}$ For this purpose, in 2000, the CALFED devised a plan to manage the basins in the next 30 years. In 2002, the California Bay-Delta Authority started to monitor the implementation of the plan.

As well as working as lawmakers, politicians approve the budgets to conduct projects in their jurisdictions. In environmental issues in the U.S., the Republicans are normally backed by farmers and extractive industries. The Democrats are backed by environmentalists. In the Hamilton City project, a former State Assemblyman Dick Dickerson, former State Senator Maurice Johnannessen, U.S. Congressman Wally Herger, and U.S. Senator Barbara Boxer have been engaged. The former three are the Republican; Senator Boxer is a Democrat (A Hamilton City citizen, interview, 24/March/2005). ${ }^{11}$

The other type of actors is non-governmental organizations outside Hamilton City. Sacramento River Conservation Area Forum (SRCAF) facilitates local meetings and drafts and implements local plans to promote restoration on the Sacramento River. ${ }^{12}$ It also tries to expand the support on state's and CALFED's restoration efforts. The Nature Conservancy (TNC) is an international conservation organization to purchase land for restoration and conservation. ${ }^{13}$

\section{The Organizations' Roles and Networks in the Hamilton City Project}

In this section, the specific roles and connections of organizations for the Hamilton City project are explained (Fig. 2 shows major connections). For decades, Hamilton City residents including volunteer firefighters and the HCCSD fought against flooding. When the reconstruction of the "J" Levee was studied by public agencies such as the USACE, Hamilton City residents could continuously participate in public meetings to see the situation (USACE and Reclamation Board, 2004). At the same time, the HCCIA members participated in the meetings outside Hamilton City to show the local needs on the project (A HCCIA members, interview, 23/March/2005). Bill Paris helped the HCCIA in the presentations as he worked as a legal consultant for the HCCIA and the HCCSD. While he went to meetings and negotiated with outside agencies and organizations, he helped the members in the presentations. As a result, the members could go to the meetings, and they could cut the costs to pay Bill Paris for participating in all meetings. Moreover, upon request, Bill Paris helped state officials to present the Hamilton City project in Washington, D.C. (A Reclamation Board member, interview, 3/ June/2005).

In addition, the HCCIA plays a major role in fundraising inside Hamilton City for the levee construction. In the mid 1990s, the HCCSD started fundrais- 


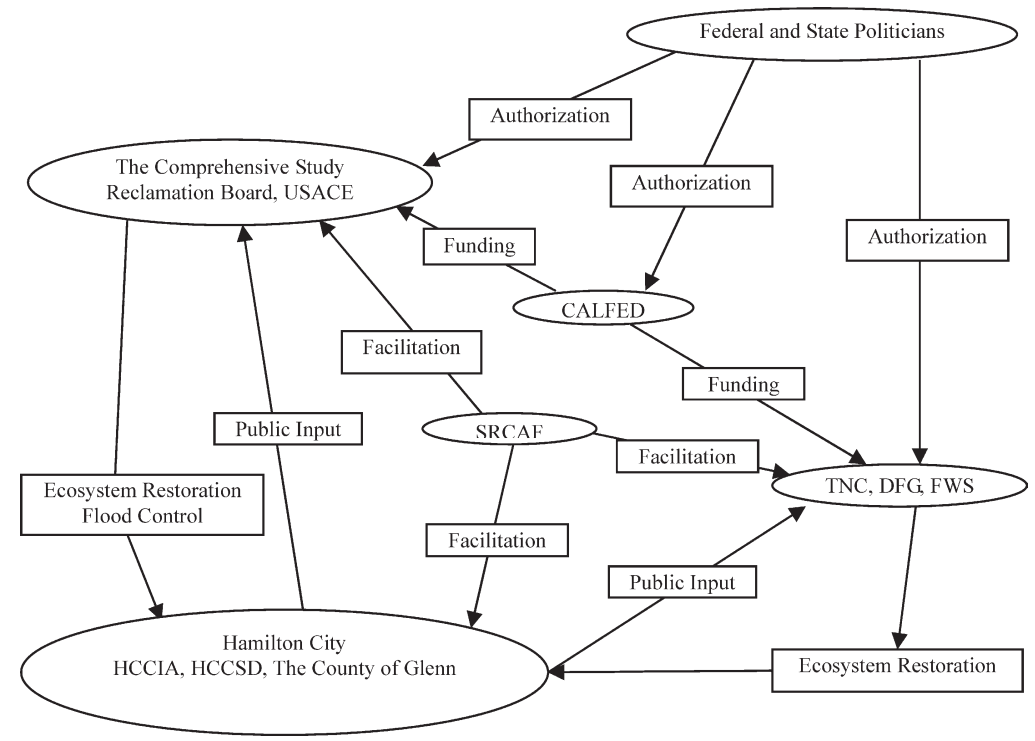

Fig. 2 The Organizations' Roles and Network in the Hamilton City Project Produced by the author

ing to start a new feasibility study to reconstruct the levee as it communicated with USACE and the State Reclamation Board (HCCIA, 2004). \$125,000 was demanded (Chico ER [Chico, CA], 18 June 2002). Soon after they found they could not legally raise funds for this matter, they handed over this role to the HCCIA (A HCCIA member, interview, 23/March/ 2005). To continue fundraising, the HCCIA started the levee festivals. In the festivals, the USACE, TNC, and the HCCSD show the progress of the Hamilton City project in their booths. State and federal politicians visited the festivals and write to the HCCIA to recognize the levee festivals and the project. After the festivals, local news media covered the festivals, the Hamilton City project, and the visiting politicians (Chico ER [Chico, CA], 18 June 2002 ; Press-Register [Orland, CA], 17 October 2001). The HCCIA compiled the news articles into a booklet and sent it to the politicians (A HCCIA member, interview, 23/March/ 2005 ; HCCIA, 2004).

At a state government level, the DWR staffs have been knowledgeable about the Hamilton City project (a state official, interview, 3/June/2005). It provides the technical advice for the Reclamation Board. It also assists the SRCAF ; for example, it plays a role as the Forum's public relations. ${ }^{14}$ The DFG and the CWCB cooperate with the FWS and TNC to apply for the grant from CALFED to progress ecosystem restoration on the Sacramento River including the sites adjacent to the Hamilton City project (TNC, 2003). The CalTrans opposes the current design of levee in the 2004 Hamilton City Study because it seems too costly to move the State Highway 32 right north of the town (A Reclamation Board member, interview, 3/June/ 2005).

Like the DWR, the State Reclamation Board has been familiar with the Hamilton City project. From 1997 to 2002, the Reclamation Board became the lead agency in the state to conduct the Sacramento and San Joaquin River Basins Comprehensive Study (the Comprehensive Study) (A Reclamation Board member, interview, 3/June/2005; USACE and Reclamation 
Board, 2002). Together with the USACE, by this study, the Reclamation Board explored the systematic approach to integrate ecosystem restoration with flood control on the Sacramento and San Joaquin River Basins. This study recognized the Hamilton City project (USACE and Reclamation Board, 2002). However, after the legislatures stopped the Comprehensive Study, the Reclamation Board and USACE cooperated to draw the fund from CALFED for the completion of the 2004 Hamilton City feasibility study (A Reclamation Board member, interview, 3/June/2005; A state official, interview, 3/June/2005).

For the Hamilton City project, as one of federal agencies, the USACE conducted studies to find the feasibility to improve the situation of the "J" Levee. Especially since the Comprehensive Study started, it has tried to see the possibility to add ecosystem restoration to the Hamilton City project. In the 1970s and the 1980s, the USACE conducted two studies for the flood issue in Hamilton City (USACE and Reclamation Board, 2004). One was not supported by the community of Hamilton City ; the other could not find economic feasibility to construct a levee. As explained above, the USACE became the federal agency to lead the Comprehensive Study (USACE and Reclamation Board, 2002, 2004). In the process of the 2004 Hamilton City Study, there were three public meetings in Hamilton City (USACE and Reclamation Board, 2004). In these meetings, the officials from the USACE presented the alternatives and consulted the participants about the project (Chico ER [Chico, CA], 18 January 2003). In the levee festivals, the USACE set up a booth to show the progress of the Hamilton City project with TNC. The FWS applied for CALFED's funds to purchase land with the state agencies and TNC as mentioned above (TNC, 2003).
CALFED provided the crucial fund to advance the Hamilton City project. In 1997, it funded TNC and the federal and state agencies (TNC, 2003). For the 2004 Hamilton City Study, CALFED funded the State Reclamation Board and the USACE (California BayDelta Authority, 2002 ; Press-Register [Orland, CA], 25 September 2002 ; Sacramento Valley Mirror [Artois, CA], 21 September 2002). ${ }^{15}$

In cooperation with federal and state agencies to conduct ecosystem restoration, TNC, an international environmental organization, purchased land (TNC, n.d.). To manage the land, TNC involved the local stakeholders led by the HCCSD to conduct geological and hydraulic studies (Ayres Associates, 2002). To promote ecosystem restoration in the Hamilton City project, TNC offered to donate these properties to pay the state and local share to complete the Hamilton City project (Press-Register [Orland, CA], 17 October 2001). This solidified the support of Hamilton City community for TNC's ecosystem restoration. Also, at the levee festivals, TNC with the USACE set up the booth. After the Comprehensive Study recognized the Hamilton City project from 1999, the SRCAF facilitated bimonthly meetings, Hamilton City Work Group meetings, to involve local Hamilton City citizens and other stakeholders (Chico ER [Chico, CA], 16 Oct. 2003). From the mid 1990s, ecosystem restoration on the Sacramento and San Joaquin River Basin involved various participants and became a conflictive issue (Singh, 2004). The facilitating meetings seemed to be one of major occasions to hear various potentially conflicting participants in order to make progress on ecosystem restoration in Hamilton City (A HCCIA member, interview, 23/March/2005).

The legislature has justified the decisions to carry out the Hamilton City project in terms of funding and 
organizational arrangement while the Comprehensive Study was abandoned. Because of the lack of support in the legislature, the USACE and the State Reclamation Board stopped the Comprehensive Study (A state official, interview, 3/June/2005). The Hamilton City project continues because it can maintain the support of both the Republicans and Democrats from county to federal levels. The Republicans pursue the interest of a rancher and residents in Hamilton City ; the Democrats do for TNC (A state official, interview, 3/June/ 2005). In addition, politicians are invited to the levee festivals to expose both politicians and the Hamilton City project to news agencies (Press-Register [Orland, CA], 17 October 2001 ; 23 October 2002). Also, consulted by Hamilton City residents, an attorney orchestrates the lobbying activities with politicians from county to federal levels (A state official, interview, 3/ June/2005 ; SRCAF, 2004).

\section{The Development of the Hamilton City Project}

\section{The Story of Local Struggle to 2002}

The modern flood threats started in the 1970s. The "J" Levee broke in 1974, and flood fighting was often necessary to avoid levee failure and flooding (USACE and Reclamation Board, 2004). At the same time, evacuations were necessary six times from 1983 to 1998 (USACE and Reclamation Board, 2004). The Sacramento River also threatens the farmers near the river.

In 1975 and 1986, the USACE conducted the studies to renovate the levee in Hamilton City. However, after all, no formal action was taken based on these studies. Some residents got tired of this situation (interview, 24/March/2005 ; 29/March/2005). Moreover, in 1996, the major employer, Holly Sugar, closed their sugar beet processing plant. This further reduced economic feasibility to justify construction of a new levee (Chico ER [Chico, CA], 17 June 2003).

In the mid 1990s, the HCCIA started to raise funds for the levee construction (HCCIA, 2004). The HCCSD started to go door-to-door, asking people to donate. After a while, as the HCCSD found they could not legally be a control entity to keep the money earmarked for the feasibility study, it turned the job over to the HCCIA in 1998 (A HCCIA member, interview, 23/March/2005). Since then, the HCCIA has played a key role in the levee project in the community.

To raise money and to appeal to state and federal governments, the HCCIA involved town residents as volunteers, started the levee festivals, and had twelve festivals from 1998 to 2004. Each levee festival entertained 1,000 to 2,000 people in the town park, practically all residents in the town (Chico ER [Chico, CA], 18 June 2002). Each festival raises from $\$ 2,500$ to $\$ 4,700$, raising a total of $\$ 40,856$ from festivals by 2004. The festivals fell well short of the funding goal. Several news paper articles reported that the state and federal politicians came to the levee festivals and wrote to the HCCIA (Press-Register [Orland, CA], 23 October 2002; 17 October 2001). Members of the HCCIA recognized that gaining the attention of politicians was part of the essential process of getting help from governmental agencies to build the levee (interview, 23/March/2005). The HCCIA consistently gives politicians from county to federal levels invitations to every levee festival. These consistent efforts leave some impression. At least, a Reclamation Board member admitted that the levee festival succeeded in showing officials the town's need to improve the flood protection through the impression of the food. He explained, "In the CALFED meeting with several 
money discussions, you will hear some deputy director say, 'Sell damn good tacos to build the levee"” (interview, 3/June/2005, p. 15).

\section{Becoming Included in Wider Projects to 2002}

From the mid 1990s, Hamilton City came into the sights of wider governmental flood control and ecosystem restoration projects. It started to get the attention of CALFED, the Reclamation Board, and the USACE. With the CALFED's funds, TNC, an environmental NGO, and state and federal agencies started the project named Ecosystem and Natural Process Restoration on the Sacramento River: Floodplain Acquisition and Management Project (TNC, n.d.).

For this period, TNC bought about 1,900 acres (7.6 square kilometer) of lands on Chico Landing Sub-reach that are connected to the site of the 2004 Hamilton City Study (TNC, 2003). From the acquisition of land to 2003 , TNC prepared a series of studies for the management. Two studies significantly addressed the levee problem (Ayres Associates, 2001, 2002). First, a geological study investigated the foundation for future levee location and estimated the cost of the levee construction (TNC, 2003). In the latter, TNC ran the models to find the hydraulic effect of the construction of the locally preferred levee. TNC mentioned that the HCCSD played the leading role to coordinate the inputs of stakeholders (Ayres Associates, 2002). TNC's virtual levee would not remove the HCCSD-managed town sewer plant (Ayres Associates, 2002). Also, the local landowners and management entities helped the calibration of models by describing the situations of flooding (Ayres Associates, 2002). In 2001, TNC had already decided to donate their lands to pay some part of the local-share to construct the levee (Press-Register [Orland, CA], 17 October 2001). TNC hoped the results were integrated into the 2004 Hamilton City Study (TNC, 2003).

At the same time, from 1998, the State Reclamation Board and the USACE started the Comprehensive Study after the flood of January 1997 : "one of four major floods $\cdots \cdot$. to the Central Valley in the last two decades" (USACE and Reclamation Board, 2002, p. 1). ${ }^{16}$ After this event, the State Legislature and the Congress accepted the Comprehensive Study (USACE and Reclamation Board, 2002). The lead agencies for this study were the USACE (on the federal side) and the Reclamation Board (on the state side). Aligning "some of the best" USACE's personnel, the USACE became able to integrate the value of ecosystem restoration into the cost-benefit analysis for flood control projects (A Reclamation Board member, interview, 3/ June/2005, pp. 4, 6 ; USACE and Reclamation Board, 2002, p. 2). Thus, the Comprehensive Study pursued the combination of ecosystem restoration and flood damage reduction. In addition, the federal Water Resource Development Act of 2000 recommended the USACE to share the goals with the CALFED (USACE and Reclamation Board, 2002).

At the request of Glenn County and the HCCSD, the Hamilton City project was newly named Hamilton City Flood Damage Reduction and Ecosystem Restoration Project, emerged as an "Initial Project" in the 1999 report of the Comprehensive Study and a "Local Project" in the 2002 report (USACE and Reclamation Board, 2002, p. 79). According to a Reclamation Board member, this is because the Corp's past studies in Hamilton City recognized the need of the town as well as the possibility to combine flood damage reduction and ecosystem restoration (interview, 3/June/ 2005, p. 4). On October 14, 2001, the levee festival featured the signing ceremony between the HCCSD 
and Glenn County, starting the feasibility study as a local project of the Comprehensive Study. The HCCSD and the county decided that the HCCSD would borrow $\$ 150,000$ from the county (Press-Register [Orland, CA], 17 October 2001; Sacramento River Conservation Area, 2001).

\section{Drafting the 2004 Hamilton City Study}

In July 2002, however, the state and federal legislatures stopped the Comprehensive Study. The integration of ecosystem restoration into a flood management could not solidify the support of legislatures because it was not acceptable for farmers (A state official, interview, 3/June/2005; Sacramento Bee [Sacramento], 23 May 2004). In spite of this, the Reclamation Board and the USACE advanced the Hamilton City project. As the Comprehensive Study became stopped, the USACE and the Reclamation Board became desperate, and they needed some success to secure the support of politicians and communities (A Reclamation Board member, interview, 3/June/2005; A state official, interview, 3/June/2005; Sacramento Bee [Sacramento], 23 May 2004). The Hamilton City project became the one to advance because it could secure the support of both Republican and Democratic politicians (A state official, interview, 3/June/2005).

The State Reclamation Board and the USACE applied for a $\$ 420,000$ grant from the CALFED Ecosystem Restoration Program to complete the feasibility study of for the Hamilton City project (Reclamation Board, 2002). In August, 2002, the California BayDelta Authority decided to give the Reclamation Board and the USACE the full amount to complete the 2004 Hamilton City Study (California Bay-Delta Authority, 2002 ; Press-Register [Orland, CA], 25 September 2002 ; Sacramento Valley Mirror [Artois, CA], 21 September 2002). ${ }^{17}$ In September 2002, HCCSD con- vened a signing ceremony to start the 2004 Hamilton City Study (Chico ER [Chico, CA], 24 September 2002 ; Press-Register [Orland, CA], 25 September 2002 ; Sacramento Valley Mirror [Artois, CA], 21 September 2002).

In December, 2002, the Reclamation Board and the USACE started a series of meetings for the $2004 \mathrm{Ham}-$ ilton City Study (USACE and Reclamation Board, 2004, p. chap. summary: 1). The three public meetings were held in January 2003, June 2003, and May 2004. Throughout the meetings, bilingual interpreters and fact sheets were available (USACE and Reclamation Board, 2004, p. chap. $6: 3$ ).

In the first meeting, about 80 people gathered (Chico $E R$ [Chico, CA], 18 January 2003). The participants included HCCIA members and HCCSD staffs. There, a local rancher gave a speech to show his frustration, claimed that the officially constructed levee on the Butte County side caused the flood on the Glenn County side (which was only protected by the fragile "J" Levee), and insisted that the study should use the hydraulic model which the TNC made. The TNC's study was preferred by the community as this alternative could restore the ecosystem and require less change in a future levee site (Chico ER [Chico, CA], 4 February 2004). A project manager from the USACE concluded that concentrating on the Glenn County side would be more productive and the fastest way to finish the study. The evaluation of alternatives would also include the locally preferred plan (USACE, 2003).

The second public workshop was held on June 16, 2003. The USACE gave the cost estimate for each alternative (Chico ER [Chico, CA], 16 June 2003). The locally preferred plan was to construct the levee as far from the town as the "J" Levee (interview, 23/ March/2005). In this way, they could just improve 
"protection of homes, roads, and the city sewage treatment ponds," and protect more farmland than the other alternatives (Chico ER [Chico, CA], 16 June 2003). The planners needed, however, to maximize land under ecosystem restoration which would be counted toward the cost-benefit analysis. Widening the ecosystem restoration area would pay the state and local share for the construction. Moreover, if the levee was constructed closer to the river, the levee would have to be strengthened and costly. The maintenance of the levee was also the issue (Chico ER [Chico, CA], 16 June 2003).

The last public meeting was held on May 6, 2004 to introduce the recommended plan under the $2004 \mathrm{Ham}$ ilton City Study. In the plan, the new levee will extend 6.8 miles $(10.9 \mathrm{~km}$ ) with 1,500 acres (6 square kilometer) of ecosystem restoration on the waterside (Fig. 1). The total cost for the construction will be $\$ 43.8$ million which would be divided into 28.5 million dollars for the federal share (65\%) and $\$ 15.3$ million for the state and local share (35\%) (Sacramento Valley Mirror [Artois, CA], 8 May 2004 ; USACE and Reclamation Board, 2004, p. chap. $9: 11$ ). The donation of TNC lands to public agencies such as the FWS and DFG would pay the state and local share (Sacramento Valley Mirror [Artois, CA], 3 July 2004). The annual maintenance cost will be $\$ 55,000$. As a result, the 2004 Hamilton City Study reflected the will of the local community. Initially, the people in the town were against the levee which would have tightly surrounded the town (USACE and Reclamation Board, 2004). The HCCSD and the local landowners could be content with the recommended plan which was based on their existing levee alignment.

While Hamilton City has not had a new levee constructed yet (as of 2011), it has gone through several steps (Chico ER [Chico, CA], 25 February 2001). The Hamilton City project was included in the 2007 Water Resources Development Act. In 2011, the Obama administration requested eight million dollars to pay the federal share for the construction of the project. Currently, the related agencies hope this funding will come through.

\section{Conclusion}

This study explored the change of environmental governance and the power of a corresponding poor local community through the Hamilton City project, the project to integrate ecosystem restoration with flood control along the Sacramento River, California. The project involved both traditional public agencies and non-governmental organizations such as an environmental organization from local to national scales. Since the mid 1990s, non-governmental organizations concerned about the environment, as well as state and federal agencies, have pursued the Hamilton City project designed to restore the ecosystem along part of the Sacramento River in northern California. These groups and agencies changed the scales and roles of participants in the project, accelerating construction of a levee and integrating that aspect into the plan for ecosystem restoration. Previously, the federal USACE dominated the decision-making about whether constructing the levee was feasible. Because the Hamilton City plan now included steps to restore a part of the ecosystem, various related federal and state agencies became involved, as well as environmental organizations ranging from local to international groups such as the Nature Conservancy (USACE and Reclamation Board, 2004). To facilitate the ecosystem restoration in Hamilton City, these organizations took the 
persevere step of consulting Hamilton City citizens. To this end, facilitating agents such as the SRCAF became engaged in the project (Chico ER [Chico, CA], 16 Oct. 2003). Thus, some organization such as SRCAF was established to include and coordinate participants' opinions in order to promote ecosystem restoration. $^{18}$ The community of Hamilton City persistently showed their need for levee construction. While they could not dominate environmental governance of the project, their support was indispensable. This study shows that various types of participants in environmental governance can cause a conflict as well as bring about a more horizontal relation. In this situation, some institution as part of environmental governance plays a role in the mediation of conflict. The conflict can be regarded as the contestation over scale relations as environmental governance observes the participation of various actors regardless of their traditional scales of interest (Brenner, 2001; Bulkeley, 2005, p. 883 ; Marston, 2000 ; McCann, 2003). According to Harrington et al. (2008), environmental governance means the change of decision-making from vertical to horizontal. This shift involves various institutions. This is true to the Hamilton City project. As the progress of ecosystem restoration along the Sacramento River involved various types of participants through scales, these participants such as farming and environmental interests caused the serious conflict (Singh, 2004). Some participants such as SRCAF emerged to play a role in the mediation of conflict. ${ }^{19}$

Also, when environmental governance pursues a potentially conflicting project, powerful participants might pay more attention to local needs and responses. In other words, in a controversial situation, the agreement with local people is probably indispensable for powerful participants to add local success with minimal controversy. Hamilton City residents managed to show their local need to reconstruct a local levee. While they could not decide the major direction of project, their support on the project was indispensable. Without local support, environmental organizations and public agencies could not attain the integration of ecosystem restoration with flood control. On the other hand, if a community lacks the power to voice their opinions, this can be another serious problem in terms of environmental governance.

At last, this study explored the change of environmental governance to conduct ecosystem restoration along the Sacramento River, California and the power of a corresponding poor local community. While this study mostly limited its scope within a state in the United States, environmental issues are often "transboundary” (Reed and Bruyneel, 2010, p. 5). Even at wider scales, geographers continue to observe the power relation of environmental governance through scales and its consequence. The geographic concerns can include the limited power of local communities, the dominance of powerful actors, and the difficulty of coordination among governmental organizations (Reed and Bruyneel, 2010). Thus, this study can lead to future studies which explore the effective mechanism of environmental governance to coordinate the opinions of stakeholders as well as the impact of environmental governance at a wider scale on poor people and their communities.

\section{Acknowledgement}

I thank the reviewers of this article. As well, to write this article, I thank Dr. Mary G. McDonald at the University of Hawai'i at Mānoa ; Dr. Paul Z. Melcon at California State University, Chico; Dr. Takaaki 
Koganezawa at Miyagi University of Education; Dr.

Toru Sasaki at Sapporo Gakuin University.

(Accepted, January 31, 2012)

\section{Notes}

1) U.S. Census Bureau, 2001, American FactFinder, http:www.census.gov (accessed 20-Jun-2005).

2) Northern District, Department of Water Resources, About US, http://www.nd.water.ca.gov/AboutUs/ index.cfm (accessed 3-Aug-2009).

3) Central Valley Flood Control Board, Central Valley Flood Control Board Home, http://www.recbd. ca.gov/index.cfm (accessed 3-Sep-2009).

4) California Department of Fish and Game, About the California Department of Fish and Game, http:// www.dfg.ca.gov/about/ (accessed 28-Aug-2009).

5) California Wildlife Conservation Board, A Brief Overview, http://www.wcb.ca.gov/Pages/wcb_brief_ overview.asp (accessed 28-Aug-2009).

6) California Department of Transportation, 2009, Fact Sheet: Important Events in CalTrans History, http://www.dot.ca.gov/hq/paffairs/about/cthist.htm (accessed 5-Sep-2009).

7) United States Army Corps of Engineers Headquarters, 2007, US Army Corps of Engineers : A Brief History, http://usace.army.mil/History/Pages/Brief/ index.html (accessed 1-Sep-2009).

8) U.S. Fish \& Wildlife Service, Who We Are, http:// www.fws.gov/who/ (accessed 3-Sep-2009).

9) Division of Realty, U.S. Fish and Wildlife Service, Division of Realty Guide for Landowners, http:// www.fws.gov/realty/lap.html (accessed 3-Sep2009).

10) CALFED Bay-Delta Program, 2007, About CALFED, http://calwater.ca.gov/calfed/about/index.html (accessed 5-Sep-2009).

11) Dickerson, D, About Dick Dickerson-Biography, http://dickdickerson.com/about/ (accessed 3-Sep2009). Shasta County, California, Candidate, http://www.elections.co.shasta.ca.us/OfficeCandi date. aspx $?$ eid $=28 \&$ oid $=19 \& c i d=3213$ (accessed 3-Sep-2009).

12) Sacramento River Conservation Area Forum, SRCAF Home, http://www.sacramentoriver.org/ srcaf/ (accessed 7-Sep-2009).

13) The Nature Conservancy, About The Nature Conservancy, http://www.nature.org/aboutus/ (accessed 7-Sep-2009).

14) Above 12.

15) The Reclamation Board of the State of California, Regular Board Meeting, 2003, Meeting Transcripts, http://recbd.ca.gov/reports/2003/transcript-3-03. doc (accessed 4-Jul-2005).

16) California Data Exchange Center, Division of Flood Management, California Department of Water Resources, Sacramento River at Hamilton City (HMC) : River Stage, http://cdec.water.ca.gov/cgiprogs/selectQuery?station_id $=$ HMC\&dur_code $=$ E\&sensor_num $=1 \&$ start_date $=06 / 01 / 2005+00$ : $00 \&$ end_date $=$ now $($ accessed 1-Jul-2005).

17) Above 15.

18) Above 12.

19) Above 12.

\section{References}

Ayres Associates (2001): Geotechnical investigation of "J"-levee Sacramento River near Hamilton City, CA. In The Nature Conservancy. (2003) : Management and Monitoring Recommendations for Floodplain Habitats of the Chico Landing Subreach (RM178-206), Sacramento River California : Final Report. The Nature Conservancy, Chico, CA, appendix 4, http://www.sacramentoriverportal.org/ reports/chico_landing (accessed 15 Jun. 2005).

Ayres Associates (2002): Two-dimensional hydraulic modeling of the upper Sacramento River, RM 194.0 to RM 202.0 including riparian restoration, setback levee, and east levee removal. In The Nature Conservancy. (2003) : Management and Monitoring Recommendations for Floodplain Habitats of the Chico Landing Subreach (RM178-206), Sacramento River California : Final Report. The Nature Conservancy, Chico, CA, appendix 8, http://www.sacra mentoriverportal.org/reports/chico_landing (accessed 15 Jun. 2005).

Bakker, K. (2007) : Introduction. Bakker, K. eds. : Eau Canada: The future of Canada's water. UCB Press, 1-22. 
Brenner, N. (2001) : The limits to scale? Methodological reflections on scalar structuration. Progress in Human Geography, 25-4, 591-614.

Bulkeley, H. (2005) : Reconfiguring environmental governance : Toward a politics of scales and networks. Political Geography, 24, 875-902.

Bundy, B. (2003) : Hamilton City : A new way of doing business $\cdots$. Sacramento River Conservation Area Forum: SRCAF Notes. October. Red Bluff, CA, http://www.sacramentoriver.ca.gov/publica tions/10_29_03/october_newsletter_03.pdf (accessed 4 Jul. 2005).

Hamilton City Citizens In Action (HCCIA) (2004) : Report: Levee Study Fund Hamilton City, CA. Hamilton City Citizens In Action, Hamilton City, CA.

Harrington, C., Curtis, A. and Black, R. (2008) : Locating communities in natural resource management. Journal of Environmental Policy and Planning, 10, 199-215.

Kackert, K.M. (1995) : The Establishment of Hamilton City, California, 1905-1906 and its relation to the beet sugar industry. MA Thesis, California State University, Chico.

McCann, E. (2003): Framing space and time in the city : Urban policy and the politics of spatial and temporal scale. Journal of Urban Affairs, 25-2, 159-178.

Office of Federal Register (2002) : Notice. Federal Register, 13 December 2002, 76731-76732, http://a257. g.akamaitech.net/7/257/2422/14mar20010800/edo cket.access.gpo.gov/2002/02-31456.htm （accessed 4 Jul. 2005).

Olsson, P. (2007) : The role of vision in framing adaptive co-management processes: Lessons from Kristianstads Vattenrike, southern Sweden. Armitage, D., Berkes, F. and Doubleday, N. eds. : Adaptive comanagement: Collaboration, Learning, and MultiLevel Governance. UBC Press, Vancouver.

Paterson, M., Humphreys, D. and Pettiford, L. (2003) : Conceptualizing global environmental governance : From interstate regimes to counter-hegemonic struggles. Global Environmental Politics, 3-2, 1-10.

The Reclamation Board of the State of California (Recla- mation Board) (2002): Hamilton City Ecosystem Restoration and Flood Damage Reduction. Sacramento, CA. http://calwater.ca.gov/Programs/Eco systemRestoration/2002_Proposals/261DA/ HamiltonCity_261DA_RevisedProposal.pdf (accessed 4 Jul, 2005).

Reed, M.G. and Bruyneel, S. (2010) : Rescaling environmental governance, rethinking the state : A threedimensional review. Progress in Human Geography, 34, 1-8.

Singh, A. (2004) : Environmental Conflict along the Sacramento River: Stakeholder Perspectives on Habitat Restoration. MA thesis, California State University, Chico, Chico, CA.

Sacramento Conservation Area (2001): SRCA Notes. October. Red Bluff, CA, http://www.sacramento river.ca.gov/publications/1-13-03/oct_newsletter. pdf (accessed 4 Jul. 2005).

Sacramento River Conservation Area Forum, Board of Directors (SRCAF) (2004) : Minutes. 15 April. Willows, CA. http://www.sacramentoriver.ca.gov/publi cations/07_09_2004/apr_15_board_minutes.pdf (accessed 4 Jul, 2005).

The Nature Conservancy (TNC), Sacramento River Project (2003) : Management and Monitoring Recommendations for Floodplain Habitats of the Chico Landing Subreach (RM178-206), Sacramento River California: Final Report. The Nature Conservancy, Chico, CA, http://www.sacramentoriverpor tal.org/reports/chico_landing (accessed 15 Jun. 2005).

TNC. (n.d.) : Sacramento River Restoration : Chico Landing Sub-reach (RM 178-206). The Nature Conservancy, Chico, CA, http://ecosystem.calfed.ca.gov/ WRRC/CalFed/people/rluster/proposal/999639934 52/combilationB (accessed 10 May 2005).

U.S. Army Corps of Engineers, Sacramento District (USACE) (2003) : Public Workshop Summary: Hamilton City Flood Damage Reduction and Ecosystem Restoration, California: Feasibility Report and Environmental Impact Statement/Environmental Impact Report. 9 January. Sacramento, CA, http:// www.compstudy.org/docs/hamilton/hamilton_city_ workshop1-9-03summary.pdf (4 Jul. 2005).

USACE and Reclamation Board (2002): Sacramento and 
San Joaquin River Basins California Comprehensive

Study: Draft Interim Report. Sacramento, CA.

USACE and Reclamation Board (2004): Hamilton City
Flood Damage Reduction and Ecosystem Restoration, California : Final feasibility report and environmental impact statement/ environmental impact report.

環境ガバナンスと貧困の地元コミュニティー : カリフォルニア州ハミルトンシティーにおけ る生態系修復型堤防建設プロジェクトの展開

$$
\text { 三 宅 良 尚 }{ }^{*}
$$

本研究では, カリフォルニア州サクラメント河流域の生態系を修復するプロジェクトをハミルトン シティーで推進する環境ガバナンス，ならびに，ハミルトンシティーの住民の反応を分析した。環境 ガバナンスの理論, そして, 実践は, スケール・ポリティックスの観点から分析した。ハミルトンシ ティーは, 貧困層が多数を占めるコミュニティーであり，プロジェクトに洪水対策の堤防建設を統合 するように要求していた。それには, ローカルから連邦スケールに至る従来の利害関係者よりも,ずっ と多くの関係者が積極的に関わっており，生態系修復に関心を持つ多くの団体が加わっていた。つま り，ハミルトンシティーのプロジェクトには，国際的なものを含んだ非政府組織，連邦からローカル に至る従来から河川管理に関わる多くの政府機関，ローカルの住民が包摂された。より広域的に見る と, 非政府機関と政府機関がサクラメント河流域全体の生態系修復プロジェクトを推進する環境ガバ ナンスを創造し，やや水平的な関係を関係主体間で生み出していた。当初堤防建設だけを求めていた ハミルトンシティーの住民が生態系修復プロジェクトを受け入れ，それに参加したのは，政策的なメ リットのためである。政府は，堤防建設だけのプロジェクトを政策的に正当化できず，予算を編成で きなかったが，生態系修復を加えることで堤防建設を正当化できた。堤防建設の予算の実現を政府， 非政府機関に要求し続け, 生態系修復を推進する環境ガバナンスと歩調を合わせ, 堤防建設を前進さ せた点で住民の努力には意義があったと言える。

キーワード：環境ガバナンス, スケール・ポリティックス, 堤防建設, 生態系修復, アメリカ合衆国

* Ph.D. Candidate, Department of Geography, the University of Hawaìi at Mānoa 